Applications in the Nuclear Industry for Corrosion-Resistant Amorphous-Metal Thermal-Spray Coatings

J.C. Farmer, J-S. Choi

August 31, 2007 
This document was prepared as an account of work sponsored by an agency of the United States Government. Neither the United States Government nor the University of California nor any of their employees, makes any warranty, express or implied, or assumes any legal liability or responsibility for the accuracy, completeness, or usefulness of any information, apparatus, product, or process disclosed, or represents that its use would not infringe privately owned rights. Reference herein to any specific commercial product, process, or service by trade name, trademark, manufacturer, or otherwise, does not necessarily constitute or imply its endorsement, recommendation, or favoring by the United States Government or the University of California. The views and opinions of authors expressed herein do not necessarily state or reflect those of the United States Government or the University of California, and shall not be used for advertising or product endorsement purposes.

This work was performed under the auspices of the U.S. Department of Energy by University of California, Lawrence Livermore National Laboratory under Contract W-7405-Eng-48. 


\title{
Applications in the Nuclear Industry for Corrosion-Resistant Amorphous-Metal Thermal-Spray Coatings
}

Joseph Collin Farmer and Jor-Shan Choi

Lawrence Livermore National Laboratory, Livermore, California USA

Keywords: Fe-based, Amorphous Metal, Coatings, Applications

\begin{abstract}
Amorphous metal and ceramic thermal spray coatings have been developed that can be used to enhance the corrosion resistance of containers for the transportation, aging and disposal of spent nuclear fuel and high-level radioactive wastes. Fe-based amorphous metal formulations with chromium, molybdenum and tungsten have shown the corrosion resistance believed to be necessary for such applications. Rare earth additions enable very low critical cooling rates to be achieved. The boron content of these materials, and their stability at high neutron doses, enable them to serve as high efficiency neutron absorbers for criticality control. Ceramic coatings may provide even greater corrosion resistance for container applications, though the boron-containing amorphous metals are still favored for criticality control applications. These amorphous metal and ceramic materials have been produced as gas atomized powders and applied as near full density, non-porous coatings with the high-velocity oxy-fuel process. This paper summarizes the performance of these coatings as corrosion-resistant barriers, and as neutron absorbers. Relevant corrosion models are also discussed, as well as a cost model to quantify the economic benefits possible with these new materials.
\end{abstract}

\section{Introduction}

The outstanding corrosion resistance that may be possible with amorphous metals was recognized several years ago [1-3]. Compositions of several Fe-based amorphous metals were published, including several with very good corrosion resistance. Examples included: thermally sprayed coatings of Fe-10Cr-10-Mo-(C,B), bulk Fe-Cr-Mo-C-B, and Fe-Cr-Mo-C-B-P [4-6]. The corrosion resistance of an Fe-based amorphous alloy with yttrium (Y), $\mathrm{Fe}_{48} \mathrm{Mo}_{14} \mathrm{Cr}_{15} \mathrm{Y}_{2} \mathrm{C}_{15} \mathrm{~B}_{6}$ was also been established [7-9]. Yttrium was added to this alloy to lower the critical cooling rate. Several nickel-based amorphous metals were developed that exhibit exceptional corrosion performance in acids, but are not considered in this study, which focuses on Fe-based amorphous metals. Thermal spray coatings of crystalline nickel-based alloy coatings have been deposited with thermal spray technology, but appear to have less corrosion resistance than comparable nickel-based amorphous metals [10].

A family of Fe-based amorphous metals with very good corrosion resistance has been developed that can be applied as a protective thermal spray coating. One of the most promising formulations within this family was found to be $\mathrm{Fe}_{49.7} \mathrm{Cr}_{17.7} \mathrm{Mn}_{1.9} \mathrm{Mo}_{7.4} \mathrm{~W}_{1.6} \mathrm{~B}_{15.2} \mathrm{C}_{3.8} \mathrm{Si}_{2.4}$ (SAM2X5), which included chromium (Cr), molybdenum (Mo), and tungsten (W) for enhanced corrosion resistance, and boron (B) to enable glass formation and neutron absorption [11-15]. The parent alloy for this series of amorphous alloys, which is known as SAM40 and represented by the formula $\mathrm{Fe}_{52.3} \mathrm{Cr}_{19} \mathrm{Mn}_{2} \mathrm{Mo}_{2.5} \mathrm{~W}_{1.7} \mathrm{~B}_{16} \mathrm{C}_{4} \mathrm{Si}_{2.5}$, has less molybdenum than SAM2X5 and was 
originally developed by Branagan [16-17]. In addition to SAM2X5, yttrium-containing SAM1651 $\left(\mathrm{Fe}_{48} \mathrm{Mo}_{14} \mathrm{Cr}_{15} \mathrm{Y}_{2} \mathrm{C}_{15} \mathrm{~B}_{6}\right)$ has also been explore

\section{Possible Applications}

SAM2X5 may have beneficial for applications such as the safe long-term storage of spent nuclear fuel. Specifically, these Fe-based materials could be used as relatively low-cost alternatives to more expensive nickel- and titanium-based alloys proposed for the construction of the engineered barrier system in deep geological repositories. Figure 1 shows a threedimensional illustration of nickel-based Alloy C-22 containers for spent nuclear fuel and highlevel radioactive wastes in typical drift (tunnel) at the Yucca Mountain site. Containers are protected from dripping water and falling rocks by titanium alloy drip shields.

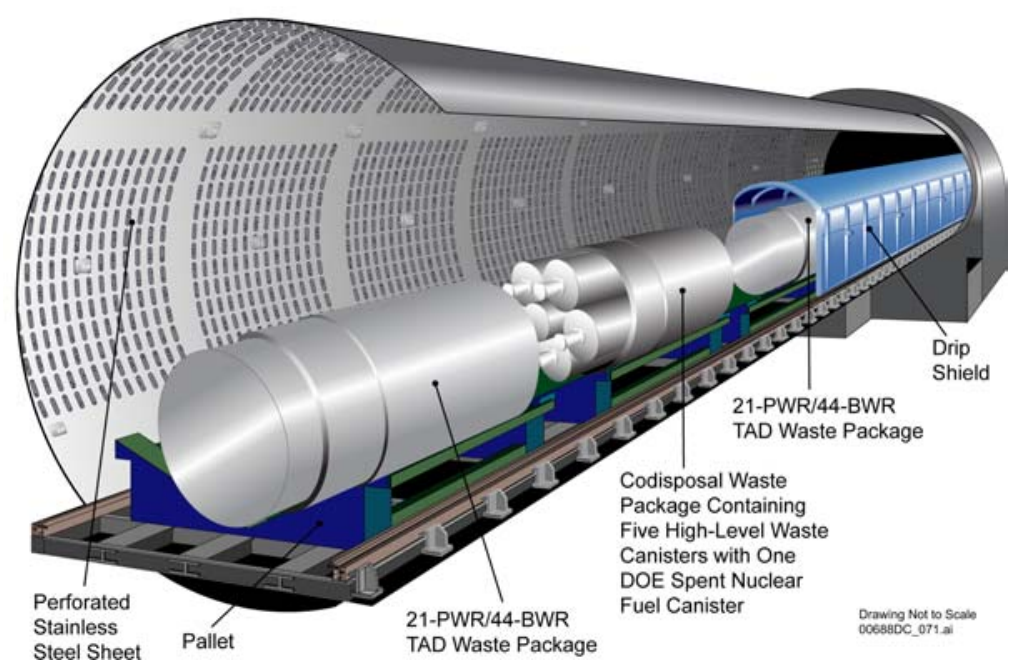

Figure 1 - Engineered Barrier System in Proposed Repository at Yucca Mountain, Nevada.

These materials have exceptional neutron absorption characteristics, and are stable at high dose. The absorption cross section in transmission for thermal neutrons for SAM2X5 coatings is three to four times ( 3 to $4 \times$ ) greater than that of borated stainless steel, and twice $(2 \times)$ as good as nickel-based Alloy C-4 with additions of Gd (Ni-Cr-Mo-Gd) [18-20]. The hardness values for Type 316L stainless steel, nickel-based Alloy C-22, and HVOF SAM2X5 are 150, 250 and 1100-1300 VHN, respectively. These materials are extremely hard and provide enhanced resistance to abrasion and gouges. In fact, successful tests have been conducted for applications as disk cutters for the tunnel boring machines. It may be possible to achieve substantial cost savings by substituting these new Fe-based materials for more expensive Ni-Cr-Mo and Ni-CrMo-Gd alloys. Thermal spray coatings of Fe-based amorphous metals are predicted to cost $\sim \$ 7$ per pound, whereas plates of Ni-Cr-Mo are expected to cost $\geq \$ 37$ per pound, based upon actual purchase costs of Alloy C-22 (UNS \# N06022), without additions of gadolinium. 


\section{Melt Spun Ribbons and Ingots}

The corrosion resistance of melt-spun ribbons and drop-cast ingots of Fe-based amorphous metals is exceptional. Cyclic polarization data for three drop-cast ingots of SAM1651 Fe-based amorphous metal with yttrium in three different environments (seawater at $90^{\circ} \mathrm{C} ; 3.5$ molal $\mathrm{NaCl}$ at $90^{\circ} \mathrm{C}$; and $5 \mathrm{M} \mathrm{CaCl}_{2}$ at $105^{\circ} \mathrm{C}$ ) is shown in Figure $2 \mathrm{a}$. All three cyclic polarization curves show outstanding passivity. Cyclic polarization data for a wrought prism of nickel-based Alloy C-22, a drop-cast ingot of Fe-based SAM1651 amorphous metal, and a melt-spun ribbon of SAM8 (SAM1651 + 3 atomic percent tungsten), all obtained with $5 \mathrm{M} \mathrm{CaCl}_{2}$ at $105^{\circ} \mathrm{C}$ is shown in Figure 2b. Both the SAM1651 and SAM8 showed passive film stability comparable to (or better than) Alloy C-22. The addition of 3 atomic-percent tungsten to the SAM1651 enhanced the passive film stability, and also yielded more ductile and damage-tolerant amorphous metal ribbons.
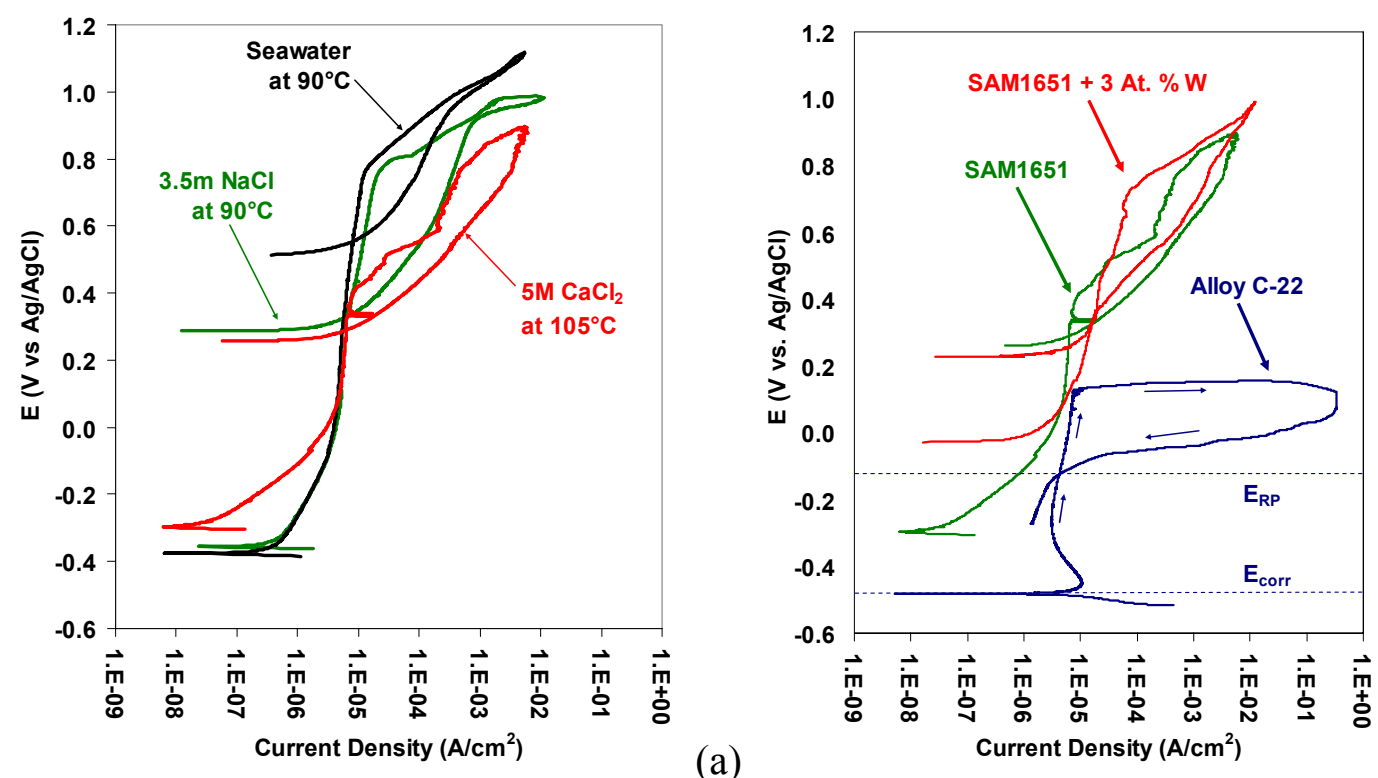

(a)

(b)

Figure 2 - (a) Cyclic polarization data for three drop-cast ingots of SAM1651 Fe-based amorphous metal with yttrium in three different environments: seawater at $90^{\circ} \mathrm{C} ; 3.5 \mathrm{molal} \mathrm{NaCl}$ at $90{ }^{\circ} \mathrm{C}$; and $5 \mathrm{M} \mathrm{CaCl} \mathrm{Cl}_{2}$ at $105^{\circ} \mathrm{C}$. (b) Cyclic polarization data for a wrought prism of nickelbased Alloy C-22, a drop-cast ingot of Fe-based SAM1651 amorphous metal, and a melt-spun ribbon of SAM8 (SAM1651 + 3 atomic percent tungsten), all obtained with $5 \mathrm{M} \mathrm{CaCl} \mathrm{Ct}_{105}{ }^{\circ} \mathrm{C}$. 


\section{Thermal Spray Coatings}

The coatings discussed here were made with the high-velocity oxy-fuel (HVOF) process (Figure 3), which involves a combustion flame, and is characterized by gas and particle velocities that are three to four times the speed of sound (mach 3 to 4 ). This process is ideal for depositing metal and cermet coatings, which have typical bond strengths of 5,000 to 10,000 pounds per square inch $(5-10 \mathrm{ksi})$, porosities of less than one percent $(<1 \%)$ and extreme hardness. The cooling rate that can be achieved in a typical thermal spray process such as HVOF are on the order of ten thousand Kelvin per second $\left(10^{4} \mathrm{~K} / \mathrm{s}\right)$, and is high enough to enable many alloy compositions to be deposited above their respective critical cooling rate, thereby maintaining the vitreous state. However, the range of amorphous metal compositions that can be processed with HVOF is more restricted than those that can be produced with melt spinning, due to the differences in achievable cooling rates. Both kerosene and hydrogen have been investigated as fuels in the HVOF process used to deposit SAM2X5 and SAM1651.

\section{Prototypical Containers}

Type 316L stainless-steel cylinders were coated with SAM2X5, and served as half-scale models of containers for the storage of spent nuclear fuel. SAM2X5-coated cylinders and plates were subjected to eight (8) full cycles in the GM salt fog test. The results of salt-fog testing are discussed in a subsequent section of this paper. Cylinders have also been coated with the Ycontaining SAM1651 and tested.
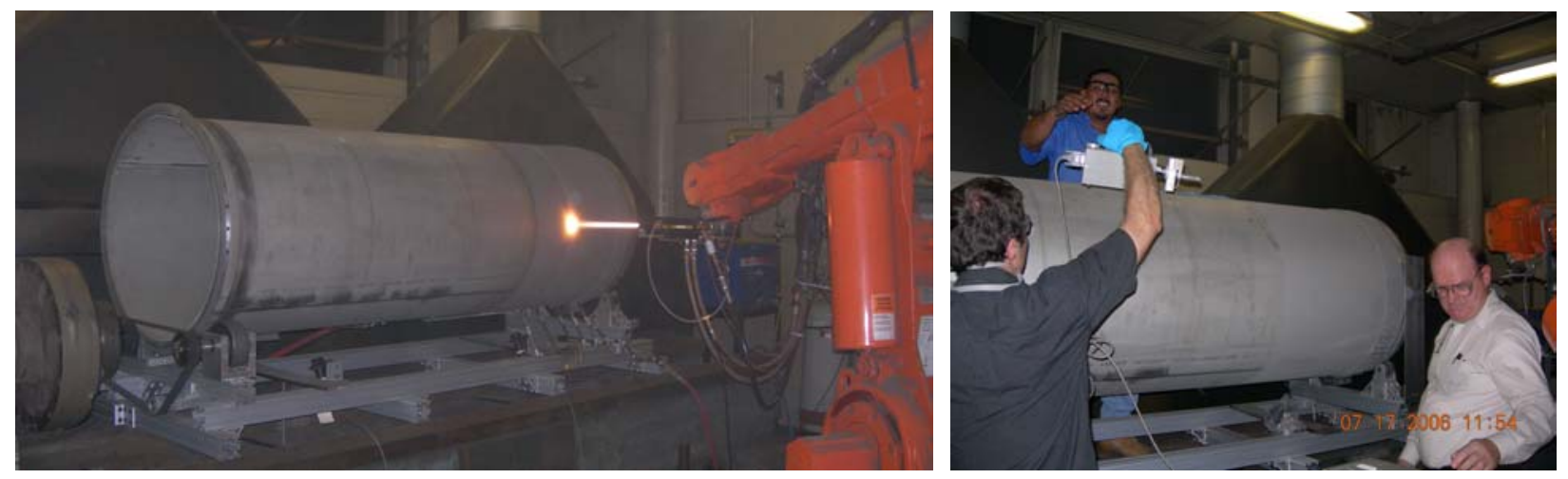

Figure 3 - Coating of Half-Scale SNF Container with HVOF Process at Caterpillar. 


\section{Coated Test Samples}

A wide variety of standardized coating samples were made for corrosion testing, as shown in Figure 4. Samples of the powders used are in the bottles at the top. Crevice samples with a bolt hole in the center are shown on the left. Alloy C-22 rods coated with SAM2X5 and SAM1651 used to monitor open-circuit corrosion potentials and corrosion rates, as determined with linear polarization, are shown on the right. Weight loss samples used for long-term immersion testing are shown in the front center. Ultra-thick $(\sim 0.75 \mathrm{~cm})$ coatings are also shown, slightly to the right of center.

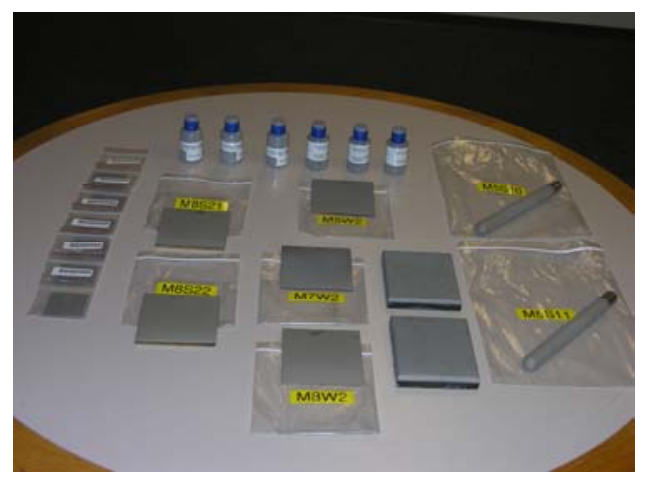

Figure 4 - HVOF Amorphous Metal Coatings Used for Long-Term Corrosion Testing.

X-ray diffraction (XRD) measurements of SAM2X5 powder (Lot \# 06-015) and thermalspray coatings made by depositing the powder on Type 316L stainless steel substrates (Figure 4). Similar results were also achieved with Alloy C-22 substrates. In regard to the thermal spray coating, the broad halo observed at $2 \theta \sim 44^{\circ}$ indicated that the coating was predominately amorphous, and the small sharp peaks are attributed to the presence of minor crystalline phases [21-22]. These phases are believed to include $\mathrm{Cr}_{2} \mathrm{~B}, \mathrm{WC}, \mathrm{M}_{23} \mathrm{C}_{6}$ and bcc ferrite, which are known to have a detrimental effect on corrosion performance. These potentially deleterious precipitates deplete the amorphous matrix of those alloying elements, such as chromium, responsible for enhanced passivity. Coatings with less residual crystalline phase have been observed.
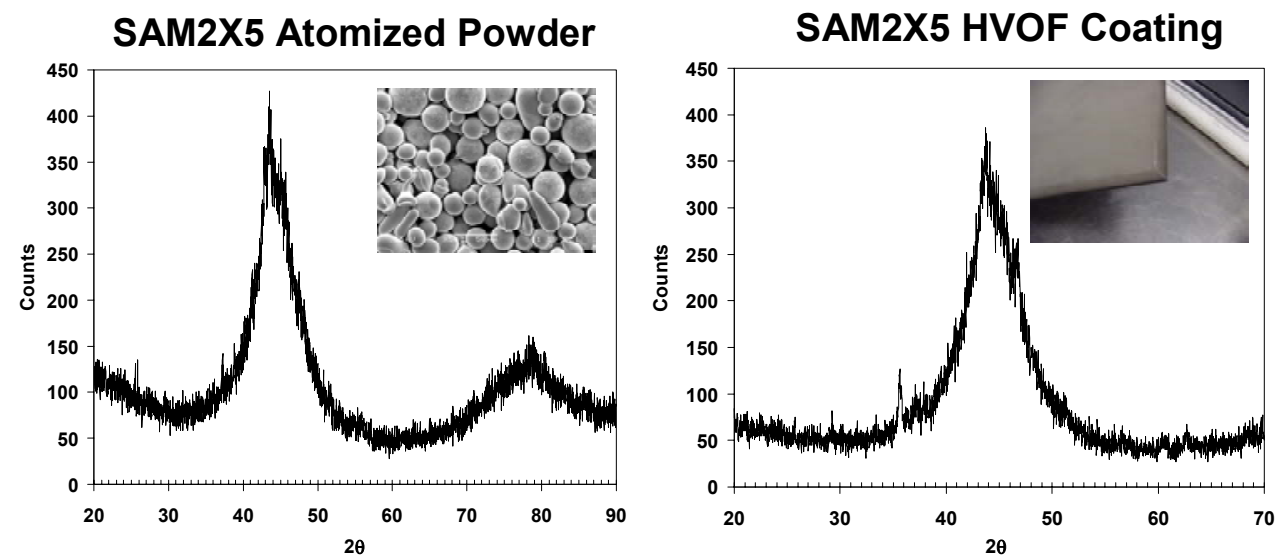

Figure 4-X-Ray Diffraction of SAM2X5 Amorphous Metal Powders and Coatings. 


\section{Corrosion Testing}

\section{Results of Long-Term Immersion Tests}

Initial corrosion-rate measurements of SAM2X5 coatings and wrought Alloy C-22 in several environments were made with linear polarization. Table 1 shows corrosion rates for Alloy C-22 and SAM2X5 in seawater at 30 and $90^{\circ} \mathrm{C}$, and in $5 \mathrm{M} \mathrm{CaCl}_{2}$ at $105^{\circ} \mathrm{C}$, after a few days immersion. The Alloy $\mathrm{C}-22$ and SAM2X5 rates were comparable in seawater, however, SAM2X5 appeared to have a lower corrosion rate in $5 \mathrm{M} \mathrm{CaCl}_{2}$ at $105^{\circ} \mathrm{C}$.

Table 1. Corrosion Rates of Alloy C-22 and SAM2X5 HVOF Coatings in Seawater

\begin{tabular}{|c|c|c|c|}
\hline Environment & Sample & $\mathrm{E}_{\text {corr }}(\mathrm{mV}$ vs. SSC) & Corrosion Rate ( $\mu \mathrm{m} /$ year) \\
\hline $30^{\circ} \mathrm{C}$ Seawater & HVOF SAM2X5 & -87.4 & 0.18 \\
\hline $30^{\circ} \mathrm{C}$ Seawater & Wrought Alloy C-22 & -163.2 & 0.09 \\
\hline $90^{\circ} \mathrm{C}$ Seawater & HVOF SAM2X5 & -241.0 & 1.58 \\
\hline $90^{\circ} \mathrm{C}$ Seawater & Wrought Alloy C-22 & -318.2 & 1.22 \\
\hline 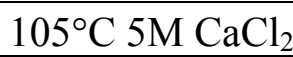 & HVOF SAM2X5 & -240.9 & 2.70 \\
\hline 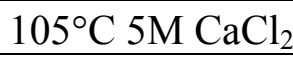 & Wrought Alloy C-22 & -464.3 & 5.04 \\
\hline $105^{\circ} \mathrm{C} 5 \mathrm{M} \mathrm{CaCl}_{2}$ & HVOF Alloy C-22 & -347.9 & 115.70 \\
\hline
\end{tabular}

Long term weight-loss and dimensional-change data for SAM2X5 were also needed. After 135 days immersion, weight-loss and dimensional measurements were used to determine the corrosion rates of SAM2X5 coatings on Alloy C-22 weight-loss samples (Figure 5). Depending upon the assumed coating density, these rates were determined to be: (1) 14.3-15.9 $\mu \mathrm{m} / \mathrm{yr}$ in natural seawater at $90^{\circ} \mathrm{C}$; (2) $8.4-9.3 \mu \mathrm{m} / \mathrm{yr}$ in 3.5 -molal $\mathrm{NaCl}$ solution at $30^{\circ} \mathrm{C}$; (3) 26.1-29.7 $\mu \mathrm{m} / \mathrm{yr}$ in 3.5-molal $\mathrm{NaCl}$ solution at $90^{\circ} \mathrm{C}$; (4) $4.6-5.1 \mu \mathrm{m} / \mathrm{yr}$ in 3.5 -molal $\mathrm{NaCl}$ and $0.525-$ molal $\mathrm{KNO}_{3}$ solution at $90^{\circ} \mathrm{C}$; (5) $8.3-9.4 \mu \mathrm{m} / \mathrm{yr}$ in $\mathrm{SDW}$ at $90^{\circ} \mathrm{C}$; (6) $2.8-3.0 \mu \mathrm{m} / \mathrm{yr}$ in $\mathrm{SCW}$ at $90^{\circ} \mathrm{C}$; and (7) $16.5-18.1 \mu \mathrm{m} / \mathrm{yr}$ in $\mathrm{SAW}$ at $90^{\circ} \mathrm{C}$. As expected, greater corrosion rates were observed at higher temperature, and nitrate anion inhibited the corrosion of these Fe-based materials in concentrated chloride solutions. Corrosion rates in bicarbonate-type brines were less than those in concentrated chloride solutions. The range of corrosive attack of SAM2X5-coated rods from a 135-day exposure to various concentrated brines at 90C is illustrated witih Figure 6. Test solutions included (a) natural seawater; (b) an aqueous solution with 3.5-molal $\mathrm{NaCl}+$ 0.525-molal $\mathrm{KNO}_{3}$; (c) neutral simulated dilute water, also known as SDW; and (d) simulated acidic water, also known as SAW. Both SDW and SAW are based upon the well J-13 water composition at Yucca Mountain. Similar data for SAM1651 coatings, based upon preliminary measurements, are shown in Figures 7 and 8. 


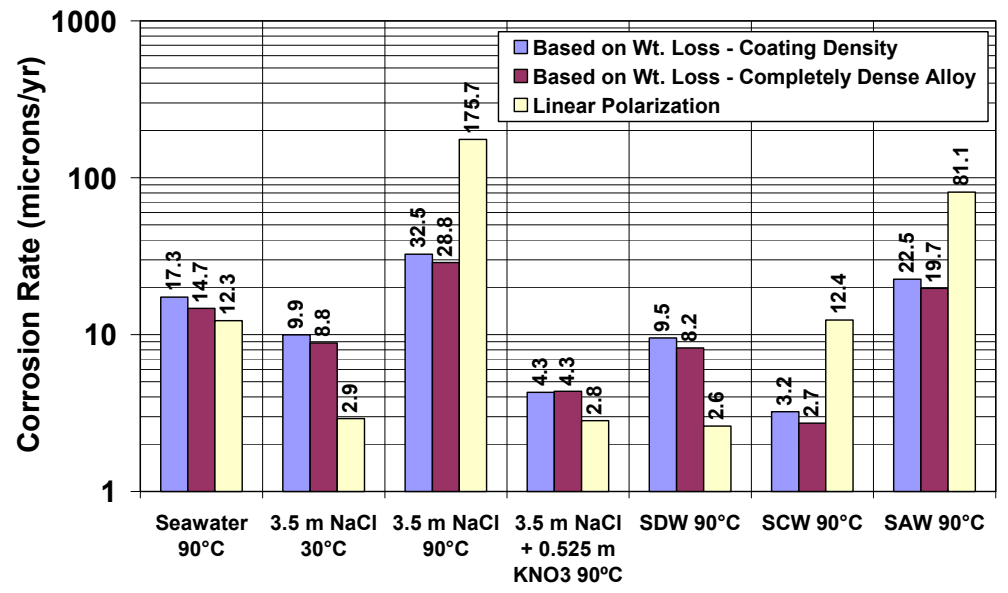

Figure 5 - Corrosion Rates of SAM2X5 Amorphous Metal Coatings After 135 Days.
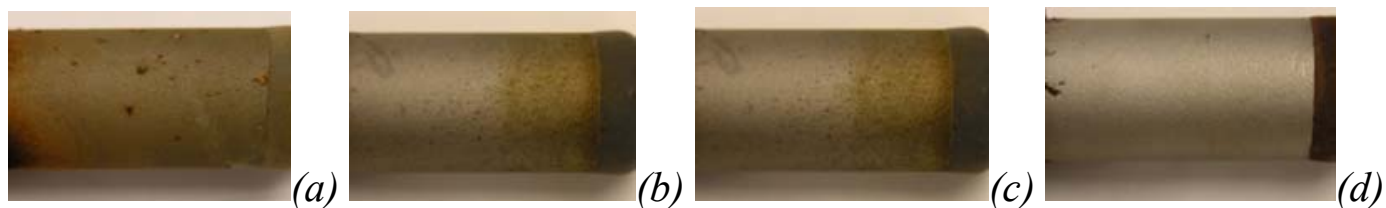

Figure 6-Corrosive Attack of SAM2X5-Coated Rods in Four Environments.

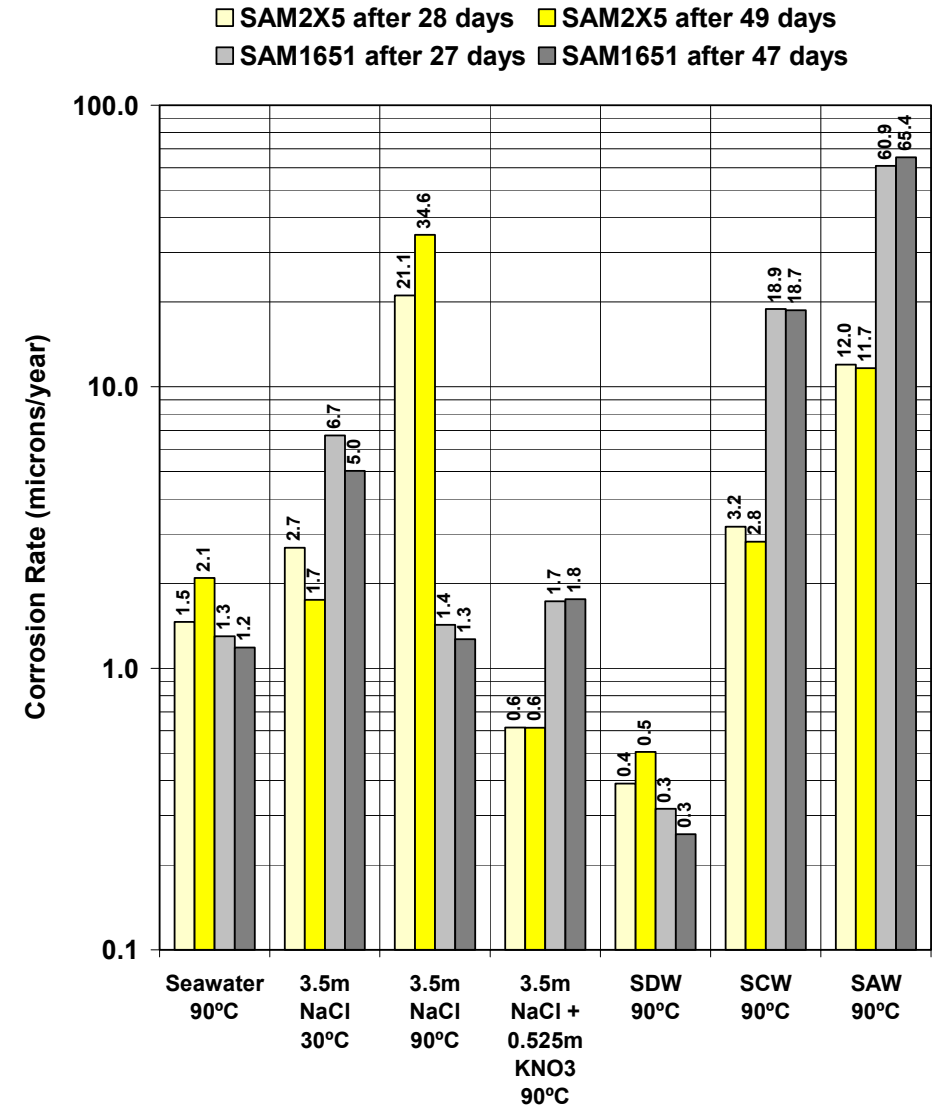

Figure 7 - Comparison of Corrosion Rates for SAM2X5 and SAM1651 Coatings. 

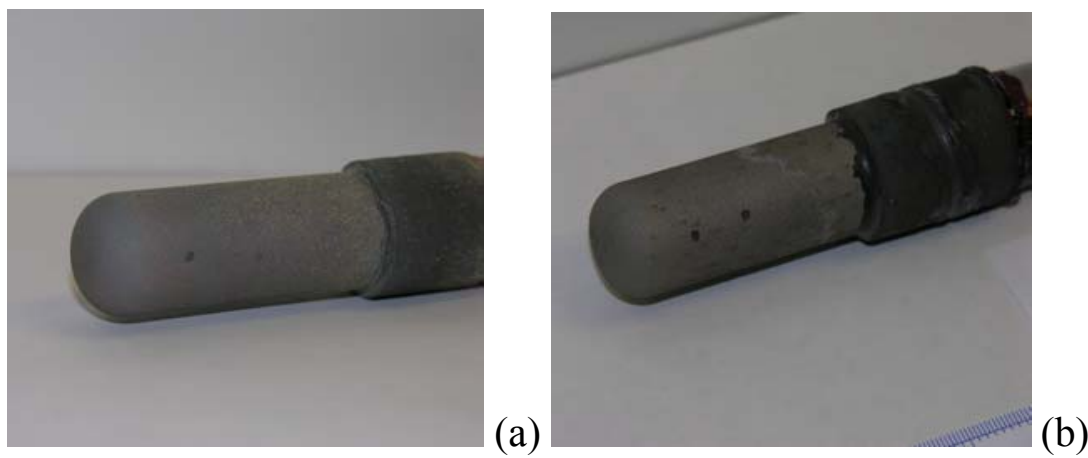

Figure 8 - Examples of Corrosive Attack of SAM1651 Coatings

After 47 Days in (a) Natural Seawater and (b) 3.5-molal Sodium Chloride Solution.

\section{Salt Fog Performance}

Several reference samples and amorphous-metal coatings have been made and subjected to salt fog testing. Salt fog tests were conducted according to the standard General Motors (GM) salt fog test, identified as GM9540P. Figure 9 shows the condition of several samples after testing: (a) 1018 carbon steel reference specimens; (b) HVOF coating of Lot \# 06-015 SAM2X5 on Type 316L stainless steel substrate, (c) HVOF coating of Lot \# 06-015 SAM2X5 on nickelbased Alloy C-22 substrate, and (d) HVOF coating of Lot \# 06-015 SAM2X5 on half-scale spent nuclear fuel (SNF) container made of Type 316L stainless steel, all after 8 full cycles in GM salt fog test. Clearly, the thermal-spay coatings of SAM2X5 have good resistance to corrosive attack in such environments. Similar testing wad done with a half-scale SNF container coated with SAM1651. This SAM1651-coated cylinder, after salt fog testing, is shown in Figure 10. Some running rust was observed on one bottom of the container, which may be due to surface preparation prior to coating.
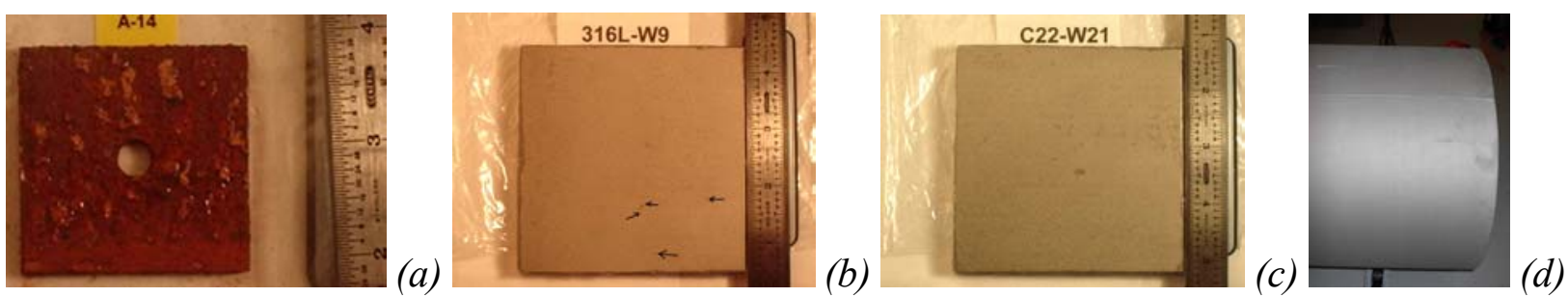

Figure 9 - Photographs of (a) 1018 Steel, (b) SAM2X5 on 316L, (c) SAM2X5 on C-22, and (c) SAM2X5 on 316L Container.
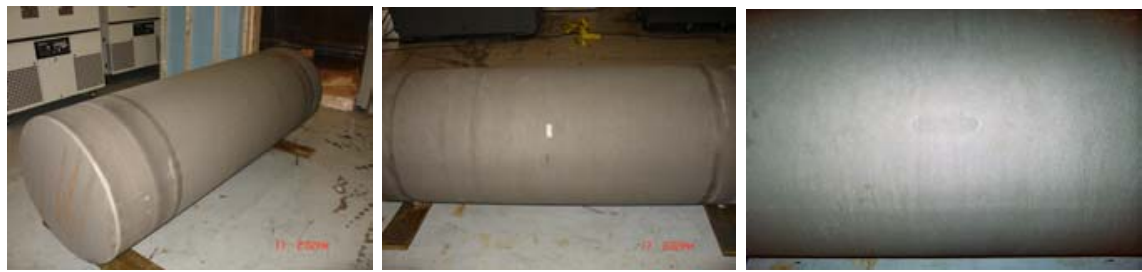

Figure 10 - Effect of GM9540P Salt-Fog Test on SAM1651-Coated Container. 


\section{Damage Tolernance}

In addition to resistance to corrosive attack, resistance to mechanical damage is also important. Figure 11a shows the non-destructive ultrasonic measurement of plate M17S1 before impact testing [Haslam et al. 2006]. The corner in the upper right was intentionally surface ground down to the level of the Alloy 22 substrate to reveal the amount of energy reflected by a completely unbonded coating. This particular plate appeared to have more variability as observed by the slight color difference at the bottom right and upper right. Note that the edges $(\sim 1 / 4 ")$ of the plate should be ignored since a focused transducer was used which is affected by edges of the substrate. Also the signal results in this figure have been mirrored appropriately so that the positions of the impacts can be identified in the associated optical photograph. This is required because the ultrasound measurements are taken from the back of the plate. Figures $11 \mathrm{~b}$ and 11c show plate M17S3 after impact testing covering a broad range of conditions. Impact velocities ranged from 9.97 to $19.22 \mathrm{ft}$ sec-1, with corresponding maximum loads ranging from 8,653 to 20,638 pounds, respectively. The slight yellow lines reflect cracks observed in some cases on the surface. The large areas with colors above red and yellow on the scale are regions where greater reflected energy is observed at the interface. A transition to greater reflected energy at the interface for the impacts on the left hand side of the plate is observed. The larger regions of higher reflected energy around the impacts appears to be consistent with the before impact Ultrasonic NDE measurements. Note that the edges $(\sim 1 / 4$ ") of the plate should be ignored since a focused transducer was used which is affected by edges of the substrate. Also the signal results in this figure have been mirrored appropriately so that the positions of the impacts can be identified in the associated optical photograph. This is required because the ultrasound measurements are taken from the back of the plate.
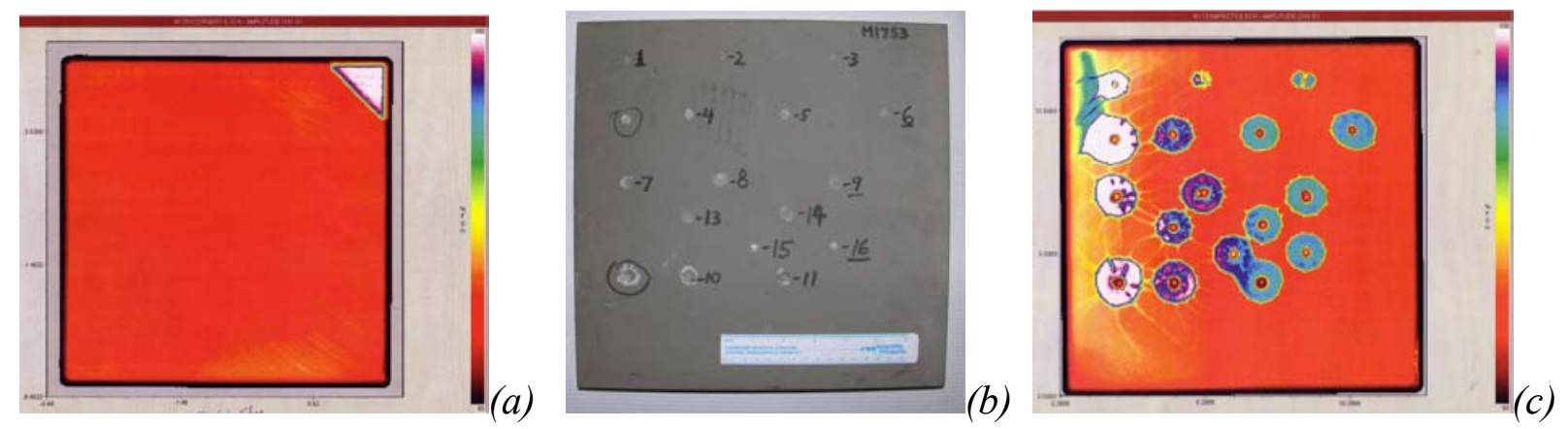

Figure 11 - Images of SAM2X5-coated plates subjected to drop-tower testing at LLNL: (a) ultrasonic non-destructive evaluation prior to impact; (b) photographs showing visible damage of after impact at various impact velocities; (c) ultrasonic non-destructive evaluation showing damage underneath coating at various impact velocities [Haslam et al. 2006]. 


\section{Economic Benefits}

A cost model was developed and used to predict the cost to produce nickel-based alloys, including Type 316 stainless steel, as well as nickel-based Alloys C-276 and C-22. This cost model used raw materials data compiled by the United States Geological Survey (USGS), and represented graphically in Figure 12. These costs were taken from the United States Geological Survey (USGS) web site, where raw materials are tracked [28].

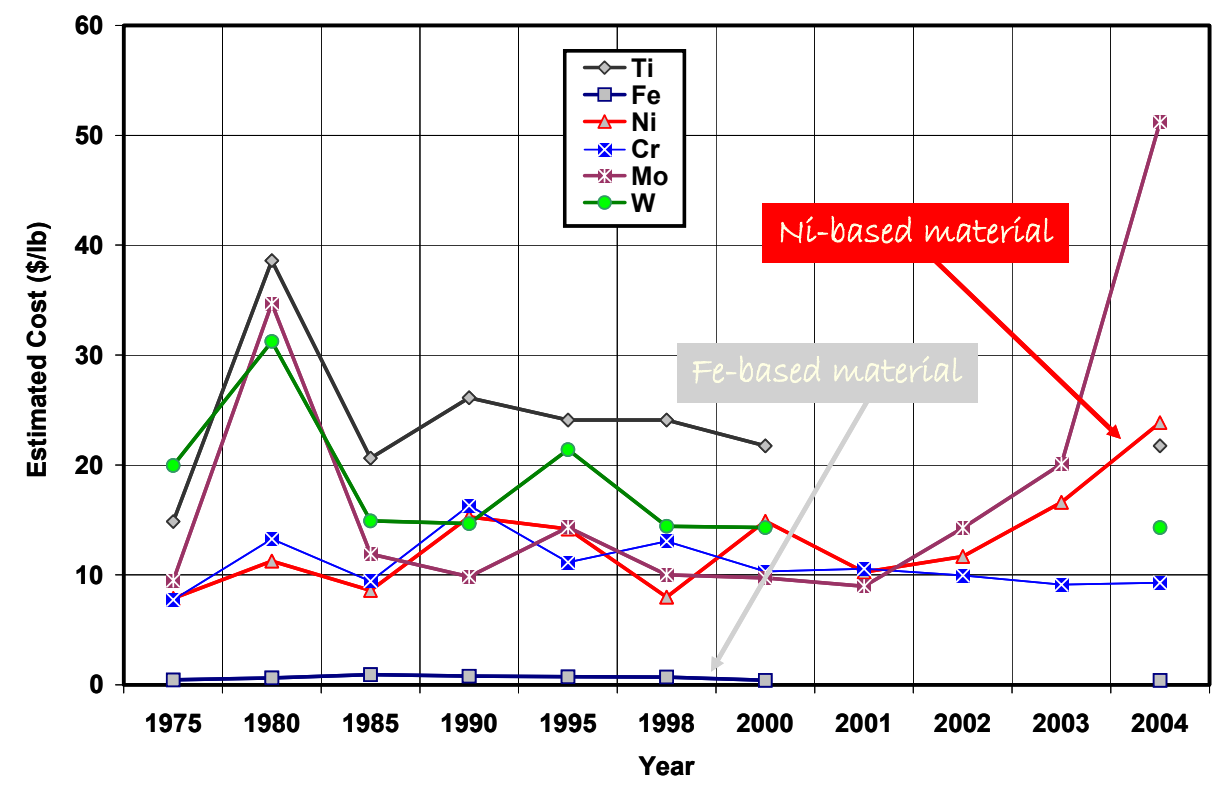

Figure 12 - Raw Materials Costs Based Upon USGS Mineral Commodity Summaries (2005).

This cost model also made the following assumptions:

1. Throughput $=1$ waste package, 1 pallet, 1 drip shield per day

2. Floor Space $=75,000$ square feet at $\$ 500$ per square foot

3. Personnel $=15 \mathrm{FTE}$ at $\$ 250,000$ per person per year

4. Equipment $=39 \mathrm{HVOF}$ guns $(30 \mathrm{lb} / \mathrm{hr})$ at $\$ 250,000$ per gun

5. $\quad$ Feed Cost $=\$ 3 / \mathrm{lb}$ (Possible); $\$ 6 / \mathrm{lb}$ (Mid Range); $\$ 8 / \mathrm{lb}$ (Bounding)

6. Cost of Nickel-Based Wrought Alloy Increasing Rapidly

Based upon this model, the estimated raw-materials costs for nickel-based Alloys C-276 and C22 were $\$ 22-23 / 1 b$. The most recent procurements of Alloy C-22 plates by these authors was at a cost of $\$ 37 / \mathrm{lb}$. More exotic nickel-based alloys proposed for use as criticality control materials, such at Ni-Cr-Mo-Gd will cost even more due to the incorporation of gadolinium as a neutron poison. The cost of Type 316 stainless steel is estimated to be approximately $\$ 7 / \mathrm{lb}$. HVOF coatings of SAM2X5 and SAM1651 are predicted to cost $\$ 10$ and $\$ 15$ per pound, respectively (Figure 13). 


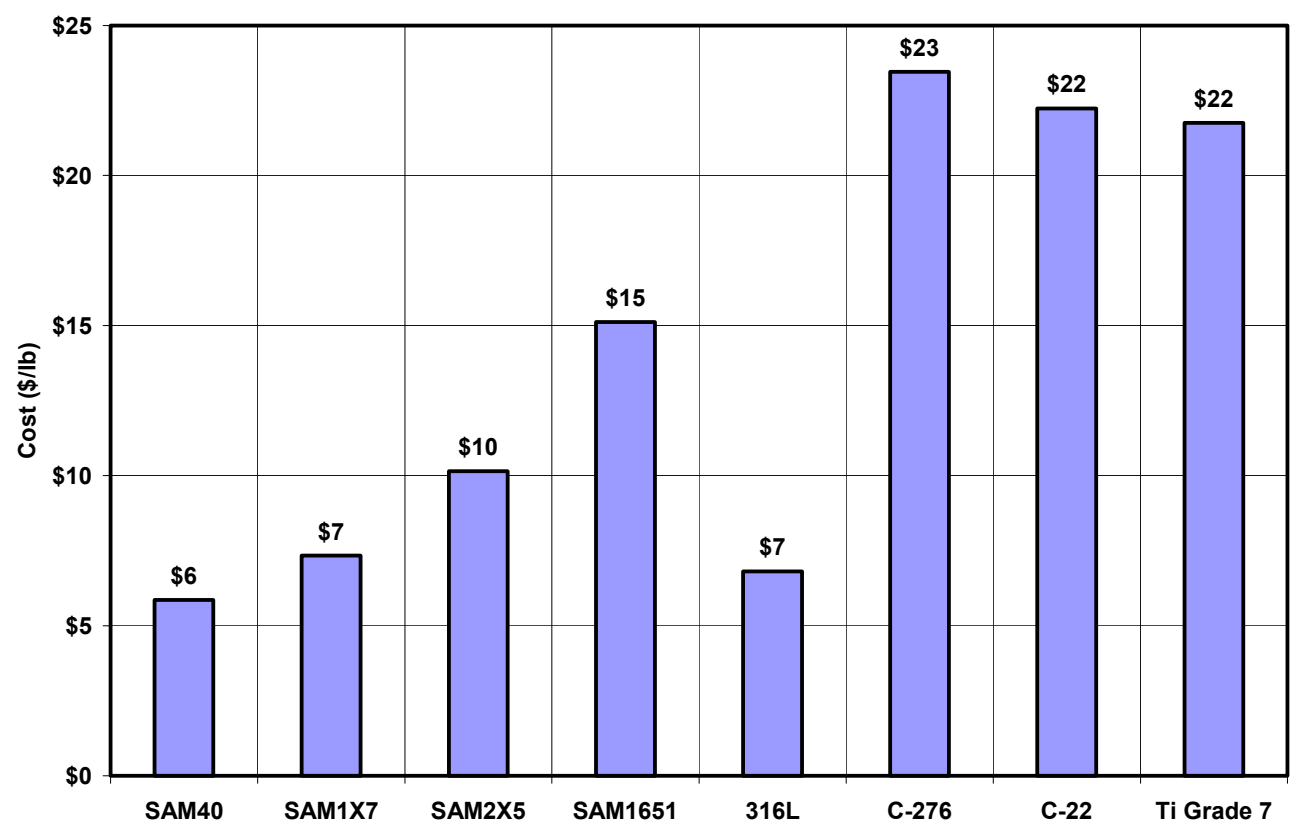

Figure 13 - Estimated Cost of Finished Materials Based Upon Figure 12.

Assuming acceptable materials performance, the following cost savings could be achieved through substitution of an Fe-based material for the more expensive nickel-based materials now specified for fabrication of SNF and HLW containers and pallets, and for titanium alloys now specified for fabrication of drip shields, all required for emplacement at the proposed repository at Yucca Mountain:

1. Assume $\$ 3 / \mathrm{lb}$ : Substantial savings are realized for the $\sim 11,000$ waste packages $(42 \%, \$ 881$ million), pallets ( $24 \%, \$ 41$ million), and drip shields ( $81 \%, \$ 2.8$ billion).

2. Assume $\$ 6 / \mathrm{lb}$ : Reasonable savings (7\%, \$271 million) for the waste package, no savings for the pallet, and large savings for the drip shield (70\%, $\$ 2.5$ billion).

3. Assume $\$ 8 / \mathrm{lb}$ : No savings are achieved for the waste package or pallet, but substantial savings can still be realized for the drip shield (63\%, $\$ 2.3$ billion).

\section{Conclusions}

Early Fe-based amorphous metal coatings had very poor corrosion resistance and failed salt-fog tests. The HPCRM Program has developed new Fe-based amorphous-metal alloys with good corrosion resistance, high hardness, and exceptional absorption cross-sections for thermal neutrons. More than forty high-performance Fe-based amorphous alloys were systematically designed and synthesized. Cr, Mo and $\mathrm{W}$ were added to enhance corrosion resistance; $\mathrm{Y}$ was added to lower the critical cooling rate; and $\mathrm{B}$ was added to render the alloy amorphous and to enhance capture thermal neutrons. Enriched boron could be used for the further enhancement of the absorption of thermal neutrons. Phase stability has been demonstrated well above $500-600^{\circ} \mathrm{C}$ and at high neutron dose (equivalent to 4000 years inside YM container). With additional development, these materials could be used to achieve cost benefits for the fabrication of nextgeneration spent nuclear fuel containers, and basket assemblies with enhanced criticality safety. Multi-ton quantities of gas-atomized SAM2X5 and SAM1651 powder have been produced and 
applied as protective coatings on numerous prototypes and parts. These new materials are now under evaluation for several applications of national importance These applications include: (1) corrosion-resistant anti-skid decking for ships and (2) criticality control material for repository

\section{Acknowledgments}

This work was performed by Lawrence Livermore National Laboratory under Contract Number W-7405-Eng-48 and under the auspices of the United States Department of Energy. Work was co-sponsored by the Office of Civilian and Radioactive Waste Management (OCRWM) of the United States Department of Energy (DOE), and the Defense Science Office (DSO) of the Defense Advanced Research Projects Agency (DARPA). The guidance of Jeffrey Walker at DOE OCRWM and Leo Christodoulou at DARPA DSO is gratefully acknowledged. The production of gas atomized powders by The NanoSteel Company and Carpenter Powder Products, and the production of coatings from these powders by Plasma Technology Incorporated and Caterpillar are gratefully acknowledged.

\section{References}

[1] M. Telford, The Case for Bulk Metallic Glass. Materials Today, Vol. 3, 2004, pp. 36-43

[2] N. Sorensen and R. Diegle, Corrosion of Amorphous Metals, Corrosion, Metals Handbook, $9^{\text {th }}$ Ed., Vol. 13, edited by J. R. Davis and J. D. Destefani, ASME, 1987, pp. 864-870

[3] D. Polk and B. Giessen, Overview of Principles and Applications, Chapter 1, Metallic Glasses, edited by J. Gilman and H. Leamy, ASME, 1978, pp. 2-35

[4] K. Kishitake, H. Era, and F. Otsubo, Characterization of Plasma Sprayed Fe-10Cr-10Mo(C,B) Amorphous Coatings, J. Thermal Spray Tech., Vol. 5 (No. 2), 1996, pp. 145-153

[5] S. Pang, T. Zhang, K. Asami, and A. Inoue, Effects of Chromium on the Glass Formation and Corrosion Behavior of Bulk Glassy Fe-Cr-Mo-C-B Alloys, Materials Transactions, Vol. 43 (No. 8), 2002, pp. 2137-2142

[6] S. Pang, T. Zhang, K. Asami, and A. Inoue, Synthesis of Fe-Cr-Mo-C-B-P Bulk Metallic Glasses with High Corrosion Resistance, Acta Materialia, Vol. 50, 2002, pp. 489-497

[7] F. Guo, S. Poon, and G. Shiflet, Metallic Glass Ingots Based on Yttrium, Metallic Applied Physics Letters, Vol. 83 (No. 13), 2003, pp. 2575-2577

[8] Z. Lu, C. Liu, and W. Porter, Role of Yttrium in Glass Formation of Fe-Based Bulk Metallic Glasses, Metallic Applied Physics Letters, Vol. 83 (No. 13), 2003, pp. 2581-2583

[9] V. Ponnambalam, S. Poon, and G. Shiflet, JMR, Vol. 19 (No. 5), 2004, pp. 1320 
[10] D. Chidambaram, C. Clayton, and M. Dorfman, Evaluation of the Electrochemical Behavior of HVOF-Sprayed Alloy Coatings, Surface and Coatings Technology, Vol. 176, 2004, pp. 307-317

[11] J. Farmer, J. Haslam, S. Day, T. Lian, C. Saw, P. Hailey, J. Choi, R. Rebak, N. Yang, J. Payer, J. Perepezko, K. Hildal, E. Lavernia, L. Ajdelsztajn, D. Branagan, Corrosion Resistance of Thermally Sprayed High-Boron Fe-based Amorphous-Metal Coatings: $\mathrm{Fe}_{49.7} \mathrm{Cr}_{17.7} \mathrm{Mn}_{1.9} \mathrm{Mo}_{7.4} \mathrm{~W}_{1.6} \mathrm{~B}_{15.2} \mathrm{C}_{3.8} \mathrm{Si}_{2.4}$, UCRL-TR-227111 Rev. 1, LLNL, Livermore, CA; 2007; JMR-2007-0058, MRS, 2007, Accepted for Publication.

[12] J. Farmer, J. Haslam, S. Day, T. Lian, C. Saw, P. Hailey, J. Choi, N. Yang, C. Blue, W. Peter, J. Payer and D. Branagan, Corrosion Resistances of Fe-based Amorphous Metals with Yttrium and Tungsten Additions in Hot Calcium Chloride Brine and Natural Seawater, $\mathrm{Fe}_{48} \mathrm{Mo}_{14} \mathrm{Cr}_{15} \mathrm{Y}_{2} \mathrm{C}_{15} \mathrm{~B}_{6}$ and $\mathrm{W}$-containing Variants, Critical Factors in Localized Corrosion 5, A Symposiun in Honor of Hugh Issacs, $210^{\text {th }}$ ECS Meeting, edited by N. Missert, ECS Transactions, Vol. 3, ECS, 2006

[13] J. Farmer, J. Haslam, S. Day, T. Lian, C. Saw, P. Hailey, J. Choi, R. Rebak, N. Yang, R. Bayles, L. Aprigliano, J. Payer, J. Perepezko, K. Hildal, E. Lavernia, L. Ajdelsztajn, D. J. Branagan, and M. B. Beardsely, A High-Performance Corrosion-Resistant Fe-based Amorphous Metal - The Effects of Composition, Structure and Environment on Corrosion Resistance, Scientific Basis for Nuclear Waste Management XXX, Symposium NN, MRS Symposium Series, Vol. 985, 2006

[14] J. Farmer, J. Haslam, S. Day, T. Lian, R. Rebak, N. Yang, L. Aprigliano, Corrosion Resistance of Fe-based Amorphous Metal Coatings, PVP2006-ICPVT11-93835, ASME, New York, NY, 2006

[15] J. Farmer, J. Haslam, S. Day, D. Branagan, C. Blue, J. Rivard, L. Aprigliano, N. Yang, J. Perepezko, M. Beardsley, Corrosion Characterization of Fe-based High-Performance Amorphous-Metal Thermal-Spray Coatings, PVP2005-71664, ASME, New York, NY, 2005

[16] D. Branagan, Method of Modifying Fe-based Glasses to Increase Crystallization Temperature Without Changing Melting Temperature, U.S. Pat. Appl. No. 20040250929, Filed Dec. 16, 2004

[17] D. Branagan, Properties of Amorphous/Partially Crystalline Coatings. U.S. Pat. Appl. No. 20040253381, Filed Dec. 16, 2004

[18] T. Lian, D. Day, P. Hailey, J-S. Choi, and J. Farmer, Comparative Study on the Corrosion Resistance of Fe-Based Amorphous Metal, Borated Stainless Steel and Ni-Cr-Mo-Gd Alloy, Scientific Basis for Nuclear Waste Management XXX, Symposium NN, MRS Series, Vol. 985, 2006 
[19] J-S. Choi, C. Lee, J. Farmer, D. Day, M. Wall, C. Saw, M. Boussoufi, B. Liu, H. Egbert, D. Branagan, and A. D'Amato, Application of Neutron-Absorbing Structural Amorphous Metal Coatings for Spent Nuclear Fuel Container to Enhance Criticality Safety Controls, Scientific Basis for Nuclear Waste Management XXX, Symposium NN, MRS Symposium Series, Vol. 985, 2006

[20] J. C. Farmer, J-S. Choi, C-K. Saw, R. H. Rebak, S. D. Day, T. Lian, P. D. Hailey, J. H. Payer, D. J. Branagan, L. F. Aprigliano, Corrosion Resistance of Amorphous $\mathrm{Fe}_{49.7} \mathrm{Cr}_{17.7} \mathrm{Mn}_{1.9} \mathrm{Mo}_{7.4} \mathrm{~W}_{1.6} \mathrm{~B}_{15.2} \mathrm{C}_{3.8} \mathrm{Si}_{2.4}$ Coating, A New Criticality Control Material, UCRL-JRNL-229505, LLNL, Livermore, CA; J. Nuclear Technology, ANS, 2007, Submitted for Publication

[21] C. K. Saw, X-ray Scattering Techniques for Characterization Tools in the Life Sciences, Nanotechnologies for the Life Science, edited by Challa Kumar, Wiley-VCH Verlag GmbH and Company, KGaA, Weinheim, 2006

[22] C. K. Saw and R. B. Schwarz, Chemical Short-Range Order in Dense Random-Packed Models, J. Less-Common Metals, Vol. 140, 1988, pp. 385-393

[23] J. E. Harrar, J. F. Carley, W. F. Isherwood, and E. Raber, Report of the Committee to Review the Use of J-13 Well Water in Nevada Nuclear Waste Storage Investigations, UCID-21867, LLNL, Livermore, CA, 1990

[24] G. E. Gdowski, Formulation and Make-up of Simulated Dilute Water (SDW), Low Ionic Content Aqueous Solution, YMP TIP-CM-06, Rev. CN TIP-CM-06-0-2, LLNL, Livermore, CA, 1997

[25] G. E. Gdowski, Formulation and Make-up of Simulated Concentrated Water (SCW), High Ionic Content Aqueous Solution, YMP TIP-CM-07, Rev. CN TIP-CM-07-0-2, LLNL, Livermore, CA, 1997

[26] G. E. Gdowski, Formulation and Make-up of Simulated Acidic Concentrated Water (SAW), High Ionic Content Aqueous Solution, YMP TIP-CM-08, Rev. CN TIP-CM-08-02, LLNL, Livermore, CA, 1997

[27] J. Farmer, S. Lu, D. McCright, G. Gdowski, F. Wang, T. Summers, P. Bedrossian, J. Horn, T. Lian, J. Estill, A. Lingenfelter, W. Halsey, General and Localized Corrosion of HighLevel Waste Container in Yucca Mountain, Transportation, Storage, and Disposal of Radioactive Materials, ASME, PVP Vol. 408, 2000, pp. 53-70

[28] Mineral Commodity Summaries, United States Geological Survey (USGS), January, 2005: Iron and Steel - M. Fenton; Cobalt - K. B. Shedd; Nickel - P. H. Kuck; Chromium - J. F. Papp; Molybdenum - M. J. Magyar and J. W. Blossom; Tungsten - K. B. Shedd; Manganese - T. S. Jones; Titanium - J. Gambogi. 